\title{
POSIBLES VÍAS INTERPRETATIVAS DE CONSTITUCIONES MISCELÁNEAS. A PROPÓSITO DE LAS CONSTITUCIONES DE PAIISES ARABO-MUSULMANES
}

\section{POSSIBLES INTERPRETIVES WAYS OF MISCELLANEOUS CONSTITUTIONS. ABOUT THE CONSTITUTIONS OF ARAB- ISLAMIC COUNTRIES}

\author{
Abdelhamid Adnane Rkioua \\ Universidad Pablo de Olavide de Sevilla \\ ahamadn@upo.es
}

Recibido: octubre de 2018

Aceptado: diciembre de 2018

Palabras clave: Constituciones, Islam, minorías, derecho a la libertad religiosa.

Key words: Constitutions, Islam, minorities, right to the religious freedom,

Resumen: Las reformas constitucionales que, cuanto menos en términos formales, recogen en varios grados las demandas sociales, reflejo del carácter plural de estas sociedades y la diversidad de proyectos políticos que se han ido gestando, dieron lugar a una miscelánea de difícil interpretación ya que ora remite al Derecho tradicional ora parece refundar el Estado a la luz de las coordenadas de corte moderno. En este panorama, puede llevarse a cabo en la práctica distintos enfoques interpretativos de las coordenadas de diferentes fuentes de inspiración, ya que las fricciones entre ambas pueden tener proyección pública, correspondiéndole al poder público afrontarlas.

\begin{abstract}
Some constitutional reforms reflect, at least in appearance and to varying degrees, the social demands that are considered a reflection of the pluralistic nature of these societies and the diversity of political projects that have been gestating. Those constitutional reforms have given rise to a myriad of regulations difficult to interpret since they sometimes refer to the traditional law and sometimes seem to rebuild the state based on modern principles. In this panorama, different interpretive approaches to the principles originating from different sources of inspiration can be carried out in practice, since the frictions between those sources can be projected publicly for the public power to address.
\end{abstract}




\section{l. Introducción}

Acierta Fátima Mernissi ${ }^{1}$ al afirmar que el mundo árabe vive un tiempo de decadencia en la Edad moderna, empero no puede colegirse de dicha aserción que "no tuviera su propia ilustración a la europea, o que ideas como democracia, derechos humanos, racionalismo o desarrollo, sean conceptos ajenos a su cultura... y aunque no exista en la actualidad verdaderas democracias, sí existe una aspiración real a la democracia, justicia y desarrollo"2. De hecho no faltan en el pensamiento arabomusulmán datos ilustrativos de épocas de apogeo y de gloria ${ }^{3}$ que permitieron cierto avance en la construcción del saber científico y tecnológico, y en las reflexiones acerca de la justicia y del buen gobierno ${ }^{4}$.

1. Mernissi, F., El miedo a la modernidad: Islam $y$ democracia. Ediciones del oriente y del mediterráneo, segunda edición, Madrid, 2007. Véase para mayor información sobre las obras de Mernissi el magnífico estudio In memorian a Mernissi de Cepedello Boiso, José., "Fátima Mernissi: un hito esencial en la historia del feminismo islámico", Revista Internacional de Pensamiento Político - I Época - Vol. 10 - 2015, pp. 173-184.

2. Marsá Fuentes, Juan., La Globalización en el Mundo Árabe a través del Discurso de sus Intelectuales. Tesis doctoral, Pág. 21, 2005. http:// digibug.ugr.es/handle/10481/649. Fecha de la última consulta 23/11/2018.

3. Véase, entre otros, Matthew E. Falagas, Effie A. Zarkadoulia, George Samonis. "Arab science in the golden age (750-1258 C.E.) and today", The FASEB Journal, vol. 20, 2006, pp. 1581-1586.

4. "La primeras opciones sustentadas en el uso de la reflexión racional, como herramienta para decidir sobre la mejor forma de gobierno, aparecen en la obra de tres de los más importantes filósofos medievales del Islam: Avicena (Black, 2001, 6466), Al-Farabi (Fakhry, 1983, 116-118) y Averroes (Jahanbakhsh, 2001, 20-21). Estos tres autores coinciden en su recurso al pensamiento platónicoaristotélico, como ayuda para decidir acerca de
Mas, es cierto que este pasado glorioso fue seguido de una larga decadencia ${ }^{5}$. A la tesis de Mernissi añade Amin Maalouf que Occidente no ve la necesidad de buscar en el pasado remoto argumentos para sentirse orgulloso, ni los occidentales tienen que remontarse a la época de Saladino o de Asurbanipal. En cambio, a los pueblos cuyo presente sólo encierra fracasos, derrotas, frustraciones y humillaciones no les queda más remedio que buscar en su pasado razones para seguir creyendo en sí mismos. Y añade, no sin razón, que el pueblo árabe "lleva doscientos años aspirando a levantarse, pero vuelven siempre a desplomarse; fueron sucediéndose derrotas, decepciones y humillaciones hasta que apareció Nasser; pensaron que con él podrían levantar cabeza, recobrar la autoestima y ganarse la admiración de los demás. Cuando volvieron a caer, a los árabes y al resto del musulmán les dio la impresión de haberlo perdido todo irremisiblemente"6. Entendemos que no ha de tomarse semejante afirmación en términos absolutos, pues de lo contrario el mundo árabe estaría abocado a una perpetua indignidad, conclusión poco científica, pues los acontecimientos históricos demuestran el afán de emancipación y de realización personal y colectiva inherentes a todo ser humano.

De hecho, los últimos años han sido marcados a partir de la denominada "primavera árabe", que dio lugar a una serie de re-

cuál sea el mejor régimen político posible." Cepedello Boiso, José., "Modelos de Organización política de la Umma en la historia del pensamiento islámico", CEFD, vol. 22, 2001, p, 15.

5. Terol Becerra, M.J., Prólogo al libro El poder constituyente en el mudo árabe, Editorial Junta de Andalucía, Sevilla, 2012, p.6.

6. Maalouf, A., El desajuste del mundo, Alianza, Madrid, 2009, p. 45. 
vueltas y de protestas populares en aras de refundar el Estado, de liberar al ciudadano del yugo del poder y de garantizar el bienestar de los ciudadanos, por unas reformas constitucionales que, cuanto menos en términos formales, recogen en varios grados las demandas sociales. Éstas oscilan entre la modernidad a ultranza y la ruptura radical con los moldes occidentales. Posiciones ambas, que si es cierto que reflejan el carácter plural de estas sociedades y la diversidad de proyectos políticos que en su seno se han ido gestando, no es menos cierto que su acogida en los nuevos textos constitucionales da lugar a una miscelánea de difícil interpretación ya que ora remite al Derecho tradicional ora parece refundar el Estado a la luz de las coordenadas de corte moderno. Ello hace que la fórmula política en dichas Constituciones sea difícil de captar, y que el sistema que de ello resulta tenga una identidad cuanto menos de difícil encaje en los patrones culturales que le sirvieron de fuente inspiración.

A luz de cuando antecede, puede afirmarse que cualquier estudioso de dichos textos constitucionales se percataría de esta palpable dualidad que hace que la unidad de sus prescripciones no resida ni en su conjunto material, sistemático y normativo, ni en la voluntad de establecer en un mismo documento una solución de compromiso que satisfaga a dos exigencias contradictorias. La operación de conjugación hizo que dichos sistemas constitucionales aparezcan como un lugar de encuentro entre dos planteamientos de distinto origen (la tradicional-musulmana y la occidental), y de ahí que provenga la complejidad palpable de unos sistemas que pretenden ser sintéticos y que resultan ser vertiginosos ${ }^{7}$. Dicho en otros

7. NACIRI, K., «Le Dualisme Constitutionnel au Maroc» «Les expériences constitutionnelles términos, esta operación de fagocitosis de lo moderno por lo tradicional y de lo tradicional por lo moderno desemboca en una síntesis inacabada, en cuanto a normación y racionalización de esta mezcolanza.

\section{Rasgos demo-liberales en las Constituciones del Norte de África}

Una lectura rápida, incluso la más precipitada, de las Constituciones del Norte de África ${ }^{8}$, que a las mismas nos limitaremos en esta parte, permitiría percatarse de la cantidad de disposiciones de planta democrática que albergan en su seno. Pues bien, aunque no se persigue aquí examinar detalladamente tales previsiones normativas, tampoco se renuncia a mencionar algunas de las mismas.

En este sentido, la Constitución marroquí del $2011^{9}$ inicia una nueva fase que, en la tónica de los modernos Estados constitucionales, introduce un completo catálogo de derechos de signo liberal, democrático y económico-social.

maghrébines», Journées d'études. Mustapha Chaker, 26 et 27 Abril 1987. Association Tunisienne de Droit Constitutionnel, Bibliothèque de Droit, de sciences politiques et économiques, Tome IX, p. 26. Al respecto escribe Palazzoli "Aussi s'agit-il d'un texte fondamentalement équivoque et qui donne un peu le vertige». In «Quelques réflexions sur la révision constitutionnelle du 1er mars 1972» PALAZZOLI. C., R.J.P.E.M. vol. 1, 1976, p. 150.

8. Omitimos el caso de Libia debido a la crisis política en la que se vive desde la caída del régimen de Gadafi.

9. Permítaseme cierta extensión con respecto a la Constitución marroquí. 
De acuerdo con ello, con razón de su centralidad, la igualdad viene anunciada a lo largo y ancho del texto constitucional ${ }^{10}$. En este orden de ideas el artículo 6.1 de la norma fundamental afirma que la ley es la expresión suprema de la voluntad social y añade que los poderes públicos y los particulares son iguales ante ella y deben someterse a sus disposiciones. El apartado segundo del mismo artículo aborda la faceta material de la igualdad incitando los poderes públicos a crear las condiciones que permitan generalizar la efectividad de la libertad y de la igualdad de los ciudadanos así que su participación en la vida política, económica, cultural y social. En línea con lo anterior, especial consideración concede el constituyente a la igualdad entre mujeres ${ }^{11} \mathrm{y}$ hombres disponiendo como garantía institucional para ello la Autoridad para la paridad y la lucha contra todas las formas de discriminación ${ }^{12}$.

10. A diferencia de lo que se estila en el Derecho Constitucional comparado, el constituyente marroquí otorga carácter normativo a las disposiciones contenidas en el preámbulo de la Constitución marroquí. De ahí que lo dispuesto en su último párrafo merezca igual atención que el articulado de la misma norma. Pues, este preámbulo, en su penúltimo párrafo hace mención expresa de la igualdad resaltando el compromiso del Estado a combatir todo género de discriminación, por razón de sexo, color, creencia, cultura, origen social o regional, lengua, discapacidad, o por cualquier otra circunstancia personal.

11. Cabe apuntar que se ha aprobado en Marruecos un proyecto de ley referido a la Convención Internacional relativa a la eliminación de todas las formas de discriminación de las mujeres, por lo que su contenido pasará a formar parte del ordenamiento jurídico nacional.

12. Otras manifestaciones de la igualdad son fácilmente detectables en el articulado de la norma fundamental marroquí. En materia electoral apunta el artículo 11.2 de la CM que los poderes públicos deben observar la estricta neutralidad
Destacado el énfasis hecho en la igualdad, ponemos brevemente de relieve dos cuestiones de interés constitucional por cuanto afectan al principio de igualdad. La primera afecta a la mujer, y la segunda guarda relación con los niños nacidos de una relación extramatrimonial.

Con relación a la primera cuestión cabe preguntarse si las disposiciones referidas a la herencia en el Código de Familia Marroquí deben pasar el control de constitucionalidad sólo a la luz del principio de igualdad o más bien se impone hacer una interpretación sistemática de la Constitución que tenga en cuenta el hecho religioso.

A propósito del segundo punto, no nos cabe sino afirmar con rotundidad el carácter inconstitucional ${ }^{13}$ de los artículos

respecto de los candidatos y la no discriminación entre ellos. Por su parte el artículo 31 de la CM garantiza la igualdad en el acceso a la salud, a la educación, a la protección social, a la formación profesional, a la educación física y artística, a la vivienda, al trabajo, al agua y a un medio ambiente saludable. Los niños, a partir de la entrada en vigor de la nueva Constitución, y con independencia de su situación familiar gozan, en virtud del artículo 32 de la CM, de igual protección jurídica e igual consideración social y moral. Asimismo se le asegura igual protección a las categorías sociales a tenor del artículo 35.3 de la CM. Como colofón a esta lista consideraciones igualitarias en lo relativo a la titularidad y ejercicio de los derechos, las disposiciones contenidas entre los artículos 37 y 40 de la norma fundamental establecen el principio de igualdad en el cumplimiento de los deberes.

13. También resulta contradictorio con los textos religiosos que le sirven al legislador de fuente de inspiración. Para más detalle, veáse Adnane, A., "Lecture croisée entre la Constitution marocaine et le cadre juridique de la filiation. La nécessaire levée de la discrimination dérivant de l'article 148 du Code marocain de la Famille", Federalismi.it, Rivista de Diritto Pubblico Italiano, Comparato y Europeo, vol. 1/2015. 
del Código de Familia Marroquí que niegan a los hijos nacidos de una relación extramatrimonial el derecho de heredar del progenitor masculino alegando la ilegitimidad de la relación sexual mantenida. Siendo ello así se le negaría también el derecho de heredar de su madre y, sin embargo, se le reconoce este derecho. Recuérdese, en este ámbito, que no sólo está en juego la herencia sino también el derecho a tener el apellido del padre, el derecho a la manutención, a la educación y la protección paterna. A esta conclusión lleva derechamente una lectura combinada de los artículos 6, 19 y 32.2 de la CM ${ }^{14}$.

Con relación al derecho a la vida, el artículo 20 de la norma fundamental trata del presupuesto ontológico necesario para el ejercicio de todos los demás derechos. Debido a ello su titularidad ha de correspondérseles a todos, nacionales y extranjeros, sin excepción. Tres consideraciones merecen ser traídas a colación con relación a este derecho. En primer lugar, el constituyente lo configura como una libertad, y de ahí que el suicidio no esté tipificado como delito en el Código penal. Ahora bien la incitación al suicidio sí está configurada como delito tal como dispone el artículo 407 del mismo Código ${ }^{15}$. En segundo lugar, y con relación al nasciturus, el legislador no optó por una prohibición

14. Véase sobre este particular Adnane, A., "Lectura en el principio de igualdad y filiación en el derecho de familia marroquí a la luz del socialismo jurídico de Antón Menguer", en Comentarios sobre el Derecho Civil y los pobres, Tirant Lo Blanch, Valencia, 2011.

15. Dispone el artículo 407 del Código Penal que "Quiconque sciemment aide une personne dans les faits qui préparent ou facilitent son suicide, ou fournit les armes, poison ou instruments destinés au suicide, sachant qu'ils doivent y servir, est puni, si le suicide est réalisé, de l'emprisonnement d'un à cinq ans." absoluta de la interrupción del embarazo ni tampoco su consideración como un derecho de la mujer encinta sino que ha adoptado una interpretación causal. Quiere ello decir que la interrupción del embarazo es considerada como un acto antijurídico que puede ser exonerado de responsabilidad penal en ciertos supuestos tal como estipula el artículo 453 del Código Penal marroquí16'17.

El corolario lógico del derecho a la vida lo encontramos en el artículo $22^{18}$ de la

16. "El aborto no es castigado cuando resulta ser una medida necesaria para salvaguardar la salud de la madre, y cuando es abiertamente practicado por un médico o cirujano con la autorización del cónyuge. Si el médico estima que la vida de la madre peligra, se prescinde de dicha autorización. A falta del cónyuge, o cuando éste rechaza otorgar su consentimiento o cuando se encuentra impedido para ello, el médico o el cirujano no puede proceder a la intervención quirúrgica o emplear una terapia susceptible de entrañar la interrupción del embarazo sólo la emisión de una declaración escrita por parte del médico-Jefe de la prefectura o de la provincia certificando que la salud de la madre no puede salvaguardarse que por medio de tal tratamiento".

17. La última cuestión relacionada con el artículo 20 de la CM está relacionada con la pena capital. Es una pena prevista para algunos hechos delictivos y la Constitución no añade nada al respecto. El artículo 23.4 de la misma dispone que el detenido "puede (y no debe) beneficiarse de los programas de reinserción". De ahí que no pueda inferirse una proscripción constitucional en términos absolutos de la pena de muerte.

18. Dispone el artículo 22 de la CM que "Il ne peut être porté atteinte à l'intégrité physique ou morale de quiconque, en quelque circonstance que ce soit et par quelque personne que ce soit, privée ou publique. Nul ne doit infliger à autrui, sous quelque prétexte que ce soit, des traitements cruels, inhumains, dégradants ou portants atteinte à la dignité. La pratique de la torture, sous toutes ses formes et par quiconque, est un crime puni par la loi." 
CM. Trata del derecho a la integridad física y moral en cuya virtud se protege la inviolabilidad de la persona contra toda intervención que suponga una lesión o menoscabo en el cuerpo no respaldada por el consentimiento del titular del derecho. El objeto protegido por tal derecho alcanza así mismo la integridad moral, por lo que quedan proscritas todas las posibles agresiones psíquicas que supongan una humillación o envilecimiento del ser humano. El segundo apartado del artículo 22 proscribe cualquier tipo de tratamientos crueles, inhumanos, degradantes 0 que atenten contra la dignidad ${ }^{19}$.

Tocante a la libertad y a las garantías del detenido, se proscribe la privación arbitraria de la libertad y se penalizan las desapariciones forzadas ${ }^{20}$. En cuanto al se-

19. En esta línea, y como elemento enriquecedor del contenido del derecho, en cumplimiento de los compromisos del Estado con los derechos humanos tal como son universalmente reconocidos, el Consejo de Gobierno ha adoptado un proyecto de ley de aprobación del protocolo facultativo a la Convención contra la tortura y otras penas o tratamientos crueles, inhumanos o degradantes del 18 de diciembre de 2002 de la Asamblea General de la ONU.

20. Respecto a la detención ilegal, el Código de enjuiciamiento criminal en sus artículos 66 y 80 aborda el asunto delicado relativo a los plazos más allá de los cuales la detención se torna ilegítima y por tanto arbitraria. Para ciertos delitos este plazo es de un máximo de 48 horas (los delitos previstos entre los artículos 163 a 218 del Código Penal) y para otras conductas ilícitas tipificadas en la ley 03-02 que modifica el Código Penal este plazo es de 96 horas. Estos plazos pueden ser ampliados previa autorización del ministerio fiscal o previa comparecencia del detenido ante el mismo que la puede decretar. Tres tipos de ampliaciones del plazo de la detención gubernativa son posibles: 24 horas como regla general y 96 horas para las infracciones contra la seguridad del Estado cabiendo otra prolongación de 96 horas cuando se trata de actos terroristas. gundo apartado del artículo 23 de la CM, se introducen ciertas garantías para el detenido, a saber el deber de ser informado de modo comprensible de los motivos de su detención (de ahí la posibilidad de un intérprete), el derecho a guardar silencio, a tener la asistencia jurídica y de comunicación con sus familiares.

Con relación a la protección de la intimidad, las dos primeras partes del artículo 24 se dispone que el domicilio es inviolable. Sin embargo sorprende que el constituyente no atribuya al juez la potestad de autorizar su violación. Por lo tanto sigue cabiendo la violación del domicilio según disponga el legislador ${ }^{21}$. Ahora bien, en lo referido a las intervenciones de las comunicaciones el artículo 24 de la CM sí añade el carácter obligatorio de la autorización judicial22.

En lo referido a la libertad de pensamiento, en virtud del artículo 25 de la CM se reconoce a todos el derecho de tener su propia concepción explicativa del hombre,

El Código de enjuiciamiento criminal aborda la validez o no de las actas de la policía judicial. En el artículo 28 del citado Código se tachan de inválidas dichas actas si no se atienen a las disposiciones legales relativas a los plazos legales. De igual modo el artículo 751 del mismo Código dispone que los actos de procedimiento contrarios a sus disposiciones se consideran no efectuados. De ahí que carezcan de fuerza probatoria en el juicio.

21. Este es el caso de la ley de procedimiento penal que permite a la policía judicial de hacerlo entre las 21.00 horas y las 06.00 horas de la mañana sin autorización judicial. De ahí que este derecho necesite ser completado por el contenido de las previsiones contenidas en los Tratados internacionales que versan sobre la materia.

22. Sin embargo la ley de enjuiciamiento criminal sigue permitiendo en su artículo 108 la posibilidad de que el ministerio fiscal autorice dichas intervenciones en algunos casos. 
del mundo y de la vida. Garantiza, pues, la existencia de un claustro íntimo, es decir de un espacio de autodeterminación intelectual ante los fenómenos sociales. Este derecho tiene clara conexión con la libertad de expresión y con el pluralismo político, presupuestos indispensables para la construcción de un marco democrático ${ }^{23}$.

En esta misma línea nos parece oportuno resaltar que el ordenamiento jurídico marroquí garantiza y protege ${ }^{24}$ ciertas manifestaciones externas de la libertad religio$\mathrm{sa}^{25}$. Se trata concretamente de los actos de culto, las reuniones o manifestaciones religiosas, la celebración de los ritos religiosos, la conmemoración de festividades, la celebración de los ritos matrimoniales.

23. Muchos derechos que derivan de esta libertad se encuentran en la nueva Constitución. Sin embargo otros faltan. Con relación a los primeros encontramos la libertad de expresión y de comunicación (art. 25), el derecho a la educación (art. 31), la libertad de asociación y de creación de los partidos políticos (art. 7 y 12), la libertad de manifestación (art. 29), la concesión de asilo por motivos de opinión, la creación literaria, artística y científica (art. 25.2). En cuanto a la segunda categoría ausente en el texto constitucional destacamos la libertad de enseñanza, la objeción de conciencia y la libertad religiosa. Sin embargo, especial atención merece esta última ya que el preámbulo proscribe la discriminación por razón de las creencias, y el artículo 11 de la CM impone la neutralidad de los poderes públicos respecto de los candidatos en las elecciones derivando de ello la prohibición de cualquier discriminación por razón de la ideología o del pensamiento por cuanto en el nuevo Estado marroquí todos los pensamientos han de estar en una posición de igualdad, y de ahí no susceptibles de ser valorados por parte del poder público.

\section{Véase artículo 220.1 del Código Penal.}

25. A tenor del artículo 223 del Código Penal se prohíbe el hecho de destruir, destrozar o ensuciar monumentos u objetos de culto.
Empero, falta un reconocimiento claro de la libertad religiosa.

Por último, en relación a la cuestión socialmente sensible de la apostasía ${ }^{26}$, ninguna norma nacional lo prohíbe expresamente. Pues a sabiendas de que en el Estado de Derecho los ciudadanos pueden hacer todo aquello que no está expresamente proscrito cabe defender su licitud en el Estado marroquí. Ahora bien, otra cuestión que sí está prohibida y no me refiero al proselitismo, que tampoco está expresamente proscrito, es el intento de influir en la fe de ciertos "colectivos" de la sociedad 27 .

En otros artículos de la Constitución se recogen los derechos liberales por excelencia. En primer lugar se garantiza la propiedad aunque, acto seguido, prevé su limitación por ley en beneficio de las exigencias del desarrollo económico y social, cabiendo la posibilidad de la expropiación. De igual modo se reconoce la libertad de empresa y la libre competencia. Así mismo se declara el compromiso del Estado con la realización del desarrollo humano duradero en aras de favorecer la consolidación de la justicia social ${ }^{28}$.

26. Se abordará la cuestión de la apostasía en el presente trabajo

27. Dispone el artículo 220.2 del Código penal que "Se castiga el empleo de medios de seducción para sacudir la fe de un musulmán o de convertirlo a otra religión, explotando para ello establecimientos de enseñanza, de salud, de asilo o de orfandad".

28. En este sentido, la Constitución marroquí recoge en su articulado una serie de derechos de naturaleza prestacional, que resultan ser concreciones de varias disposiciones, a saber del artículo 1 que define Marruecos como una monarquía constitucional, democrática, parlamentaria y social; del artículo 6.2 que dirige mandatos a los poderes públicos para crear las condiciones susceptibles de generalizar la efectividad de la 
Igual cariz moderno adquiere la Constitución tunecina, pues de entrada instaura, en su preámbulo, "un régimen republicano democrático y participativo en el marco de un Estado civil y gobernado por el Derecho y el cual la soberanía pertenece al pueblo que la ejerce sobre la base de la alternancia pacífica a través de elecciones libre, y del principio de la separación y el equilibrio de poderes".

Añádase a ello que las disposiciones de esta nueva Constitución consolidan ampliamente las libertades y derechos fundamentales, al garantizar sobre todo la libertad de creencia y de conciencia (art.6); el derecho a la vida (art.22); la protección de la dignidad de la persona y la interdicción de la tortura (art. 23); el derecho a la vida privada y la protección de la correspondencia, de las comunicaciones y de los datos personales (art. 24); la presunción de inocencia y el derecho a un proceso equitativo (art. 27); las libertades de opinión, de pensamiento, de expresión, de información y de publicación (art. 31); la libertad de opinión y de expresión (art. 31); el derecho de acceso a la información (art. 32); la libertad de cátedra (art. 33); la libertad de creación de partidos políticos, sindicatos y asociaciones (art. 35); el derecho a un medio ambiente salubre y equilibrado (art. 45).

El artículo 21 establece el principio de igualdad entre ciudadanas y ciudadanos en derechos y deberes, y afirma su compromiso a proteger y a consolidar los derechos adquiridos por la mujer (art. 46). Así mismo, en el artículo 34, la Constitución obliga al Estado

libertad y de la igualdad de los ciudadanos así como a favorecer su participación en la vida política, económica, cultural y social y del artículo 35 que evoca el concepto de justicia social que ha de modular el ejercicio de ciertos derechos de naturaleza económica. a garantizar la representatividad de las mujeres en las asambleas elegidas.

Tratándose de los derechos prestacionales, el principio de justicia social junto con el principio de discriminación positiva que propugnan, ambos, la reducción de las desigualdades, resultan garantizados por la norma fundamental. En este sentido, varios derechos sociales subjetivos han sido reconocidos tales como el derecho a la salud (art. 38), el derecho al trabajo (art. 40), el derecho a la sindicación y a la huelga (art. 36).

El artículo 49 de la Constitución introduce una expresa limitación al legislador en lo que a la limitación de dichos derechos se refiere al proscribir que la ley pueda afectar a su esencia, y al establecer el principio de proporcionalidad como parámetro de control de la actividad legislativa en esta materia. A mayor abundamiento, erige los derechos fundamentales en verdaderas cláusulas de intangibilidad frente al poder constituyente de reforma.

La Constitución de Egipto no es menos prolífica en derechos fundamentales de cuño occidental. Así, los grandes principios vienen enunciados de modo categórico.

Se garantiza, así, la dignidad de la persona, y la tortura se califica de crimen imprescriptible (art. 52 y 53). La igualdad ante la ley es total, sin consideraciones de sexo, creencia, raza, color o clase social, resaltando el carácter delictivo de la llamada a discriminación.

Se reconoce, igualmente, la libertad individual estableciendo la regla del habeas corpus, y que nadie puede ser detenido salvo en los casos de flagrante delito (art. 54). En el mismo artículo varios derechos asisten al detenido. De igual modo, se garantiza el derecho a guardar silencio y se configuran como delitos las torturas, las 
presiones y las detenciones excepcionales (art. 55), y se ordena que la privación de libertad en los centros penitenciarios, vigilada por el poder judicial, ha de tener como objetivo la rehabilitación del detenido (art. 56).

En otro orden de ideas, el artículo 57 de la Constitución garantiza la inviolabilidad de la vida privada y de las correspondencias. En el mismo sentido, se garantizan las comunicaciones electrónicas, y se prohíbe la entrada policial a los domicilios sin mandamiento judicial.

La libertad de circulación, a su vez, es de rango constitucional a la par que la libertad de residencia, y queda proscrito el exilio forzado (art. 63).

El artículo 64 reconoce la libertad de creencia en términos absolutos, y como consecuencia lógica de ello resultan garantizadas las libertades de pensamiento y de opinión. Ésta última puede manifestarse por todos los medios (art. 65). El derecho a la investigación científica y la libertad artística vienen garantizados en el artículo 66 y 67 de la norma fundamental. Se reconoce la libertad de prensa tras una simple notificación a la autoridad administrativa (art. 71), y lo mismo ocurre con las libertades de manifestación (art. 71 y 73 de asociación (74 y 75).

La constitución de los partidos políticos es libre y su disolución sólo puede decretarse por el poder judicial, y los sindicatos gozan de reconocimiento constitucional (art. 76 y 77). El artículo 87 reconoce el derecho de voto, derecho democrático por antonomasia, y se garantiza el derecho de asilo político (art. 91).

Por último, en harmonía con el Derecho Internacional de los derechos humanos, los Tratados internacionales de protección de los derechos firmado por el Estado en- tran en vigor una vez publicados sin validación posterior por el legislador.

Concluimos este repaso referido a la inscripción de las coordenadas de corte occidental en las normas fundamentales localizando las mismas en la Constitución argelina de 2016.

En línea con las mencionadas Constituciones, la norma fundamental argelina declara en el artículo 32 la igualdad de todos los ciudadanos antes la ley descartando en término tajantes cualquier trato discriminatorio, y haciendo recaer el artículo 34 en el poder público el deber de asegurar la igualdad real y efectiva en el goce y disfrute de todos los derechos. Añade en los artículos 62 y 63 la igualdad en el derecho de voto y en el acceso a los cargos públicos. Tocante al estatus de la mujer, el artículo 35 obliga al Estado a promover la paridad entre los dos sexos en el mercado de empleo y en la asunción de responsabilidades en las Administraciones Públicas.

Luego de comprometerse con la garantía de las libertades fundamentales del Hombre y del ciudadano en el artículo 38, pasa a abordarlos detalladamente. Así, a tenor del artículo 40 se garantiza la inviolabilidad de la persona humana proscribiendo toda forma de violencia física y moral o que sea atentatoria contra la dignidad. De igual modo, se anuncia que los tratamientos crueles, inhumanos o degradantes serán reprimidos por la ley, y se declara en el artículo 56 la presunción de inocencia de cualquier detenido.

Una vez garantizada la incolumidad de la persona, se pasa a garantizar la inviolabilidad de la libertad de conciencia, de opinión y de culto en el artículo 42. Lo mismo hace respecto de la libertad de creación intelectual, artística y científica prohibien- 
do el secuestro de las publicaciones salvo que medie resolución judicial (art. 44). El derecho a la cultura alcanza rango constitucional y el Estado se convierte en el sujeto obligado a proteger y a salvaguardar el patrimonio cultural nacional material e inmaterial (art. 45).

El derecho a la vida privada y al honor vienen reconocidos en la Constitución (art. 46), y se remite al legislador para su protección de igual manera que el secreto de las comunicaciones privadas cualquier que sea su forma y los datos de carácter personal. En esta misma línea, el domicilio resulta inviolable y sólo se admite su vulneración por orden judicial (art. 47).

Como corolario de este patente compromiso con los derechos fundamentales la Constitución garantiza las libertades de expresión, de asociación, de reunión y de manifestación pacífica (artículos 48 y 49). Así mismo, la libertad de prensa queda garantizada y por ende proscrita toda censura previa (art. 50). El artículo 54 reconoce la libertad de creación de las asociaciones y el artículo 52 reconoce el derecho a crear libremente partidos políticos resaltando la prohibición de fundarlos con base en criterios religiosos, raciales, corporatistas o regionales.

En lo que respecta a los derechos de índole prestacional, se recoge en el artículo 57 el derecho a la asistencia judicial gratuita para las personas en situación de necesidad, y en al artículo 65 el derecho a la enseñanza gratuita, mientras que los artículos 66 y 67 declaran respectivamente el derecho a la protección de la salud y el derecho a la vivienda. En la misma lógica de la igualdad material el Estado se compromete, entre otros, a preservar el medio ambiente (art.68) y a garantizar a todos el derecho al trabajo en condiciones salubres e higiénicas. Como colofón de esta faceta prestacional conviene apuntar que en el artículo 73 de la Constitución se garantizan las condiciones de vida para las personas que aún no pueden trabajar y a las que ya no pueden hacerlo.

Queden esbozados estos postulados constitucionales que, como ha quedado dicho, se renuncia a estudiar con el detenimiento debido, pues apenas se persigue a su propósito arrojar luz sobre algunos derechos articuladores, por excelencia, del carácter tendencialmente liberal y democrático de los citados Estados. De ello se colige que, respecto de los países arabo-musulmanes en general y del Norte de África en particular, ninguna duda cabe de su receptividad a la idea de Constitución. Así lo evidencia el que casi todos ellos cuenten con sendas Constituciones escritas. Cuestión distinta es la peculiaridad que adquieren, en su mayoría, al declarar, de un modo u otro, la confesionalidad islámica del Estado correspondiente. De ahí el calificativo de musulmanes que aquí se les aplica ${ }^{29}$.

\section{Coordenadas de cariz religioso en las Constituciones del Magreb y estado de la libertad religiosa en los países arabo-musulmanes}

3.1. Cabe señalar al inicio de este apartado que las referencias a la religión no es una práctica exclusiva de los países árabes o musulmanes, pues existen ejemplos en Latinoamérica (Argentina) y en Europa, tanto dentro (Dinamarca), como fuera

29. No huelga dejar constancia de que la excepción a esta práctica común en los países arabomusulmanes la representa el Líbano. 
(Noruega), de la Unión Europea ${ }^{30}$. 0 acaso ¿podemos imaginar una Inglaterra sin su himno patriótico "God sabe the Queen, que se remonta al siglo XVIII"? ${ }^{31}$, o se olvida el lema "In God We Trust", obligatoria en las escuelas de ciertos estados en los Estados Unidos de américa ${ }^{32}$. Hecha esta constatación, también cabe decir que ni dichas Constituciones ni su sostén social son del todo parangonables a aquellas que están siendo objeto de estudio.

En línea con ello, apuntamos que el preámbulo de la Constitución marroquí califica el Estado de musulmán y soberano. Su unidad, forjada por la convergencia de sus componentes arabo-islámico, amazig y sahariano-hassaní, se ha nutrido y enriquecido de sus afluentes africano, andaluz, hebraico y mediterráneo. La preeminencia atribuida a la religión musulmana en el conjunto de referentes nacionales va a la par con el apego del pueblo marroquí a los valores de apertura, de moderación, de tolerancia y de diálogo para la mutua comprensión entre todas las culturas y civilizaciones del mundo.

30. Fondevila. M., "Las Constituciones árabes desde el Derecho Constitucional Comparado", Revista General de Derecho Público Comparado, vol. 18, 2015, pp. 19-20. Apunta el mismo autor que aunque de modo alguno se trataba de un texto confesional, también conviene no olvidar la referencia indirecta al cristianismo que se contenía en el preámbulo de la mal llamada Constitución europea, que rezaba: "inspirándose en la herencia cultural, religiosa y humanista de Europa, a partir de la cual se han desarrollado los valores universales de los derechos inviolables e inalienables de la persona humana, la democracia, la igualdad, la libertad y el Estado de Derecho...". Nota en pie de página $\mathrm{n}^{\circ} 39$, p. 20.

31. El Mandjra, M. Humillación. El Islam sometido por Occidente. Estudio preliminar de Ramón Soriano, Editorial Almuzara, p. 47, 2005.

32. ÍDEM.
En el artículo primero se señala que la Nación se apoya en su vida colectiva sobre unas constantes federadoras, que son, entre otras, la religión musulmana moderada, la unidad nacional de afluentes múltiples. Y en el artículo tercero declara el Islam como religión del Estado, que garantiza a todos el libre ejercicio de los cultos, y en el artículo cuarto se establece que el lema del reino es Dios, Patria, Rey.

En el mismo sentido, el artículo 41 precisa que el Rey, Príncipe de los creyentes (Amir Al Muminín), vela por el respeto del islam y garantiza el libre ejercicio de cultos. Además, preside el Consejo Superior de los Ulemas, encargado de estudiar las cuestiones que se le sometan, precisando que dicho Consejo es la única instancia habilitada para pronunciar dictámenes religiosos aprobados oficialmente, sobre las cuestiones que se le sometan y ello sobre la base de los principios, preceptos y designios tolerantes del Islam. Otra referencia no menos importante a la religión se recoge en el artículo 175 que erige las disposiciones referidas a la religión musulmana, entre otras, en verdaderas cláusulas de intangibilidad.

La Constitución de Túnez, a su vez, inicia y cierra su preámbulo con referencias a Dios y enfatiza la identidad musulmana del Pueblo tunecino. En su primer artículo se establece que Túnez es un Estado libre, independiente y soberano, su religión es el Islam, su lengua el árabe y su régimen la República. El artículo sexto precisa que el Estado es el "guardián de la religión" y protector de lo sagrado, contra lo que prohíbe cualquier ataque, aunque la libertad de expresión está garantizada en el artículo trigésimo primero. De igual modo, en el artículo 39 se establece que el Estado asegura la consolidación de la identidad "árabe-musulmana", y en el artículo 74 se constitucionaliza la obligación 
de que el Presidente de la República debe ser de confesión musulmana.

Similar es el tratamiento de la cuestión religiosa en la Constitución argelina de 2016 al calificar su preámbulo el Estado como tierra del Islam, reconoce a éste, entre otros, como conjunto de valores y componentes fundamentales de su identidad. Afirma con rotundidad en su artículo segundo que el Islam es la religión del Estado y prohíbe en su artículo décimo a las instituciones realizar prácticas contrarias a la moral islámica. En virtud del artículo 195 de la Constitución queda instituido un Alto Consejo Islámico encargado de promover la innovación en materia religiosa (lytihad), de elaborar informas respecto de cuestiones religiosas sometidas a su consideración y de presentarle al Presidente un Informe periódico de su actividad. Con la misma rotundidad extiende el carácter intangible a la naturaleza islámica del Estado en su artículo ducentésimo décimo segundo.

La Constitución de Egipto de 2014, que no se aleja de estos planteamientos, destina su segundo artículo a establecer el Islam como la religión del Estado, y precisa que los principios de la Sharia islámica constituyen la fuente principal de su legislación. Mantiene en su artículo séptimo a la Universidad de Al Azhar en tanto que organismo islámico científico independiente, y basa la familia sobre la religión en el artículo noveno.

3.2. En lo que a la libertad religiosa se refiere, su acogida en las Constituciones de los países islámicos en general oscila entre su reconocimiento total y su negación ${ }^{33}$. Entre los primeros que dan plena acogida al derecho a la libertad religiosa

33. Vega Gutiérrez, A. M., "El derecho a cambiar de Religión. consecuencias jurídicas de la pertenencia y disidencia religiosa en el derecho comparado". IUS CANONICUM, Vol. 51, 2011, p. 181. en sus Constituciones ${ }^{34}$ encontramos Sudán (art. 24), Kuwait (art. 35), Irak (art. 25), Irán (art. 23), Emiratos Árabes Unidos (art. 32), Bahréin (art. 22), Líbano (art. 9), Egipto (art. 46), Siria (art. 35), Jordania (art. 14), Brunei Darussalam (art. 3.2), Pakistán (art. 20), Omán (art. 28), Libia (art. 2), Malasia (art. 11), Somalia (art. 31). En la segunda categoría se aprecia el reconocimiento de ciertas manifestaciones de la libertad religiosa, tales como la libertad de conciencia en el caso de Bangladesh (art. 39), la libertad de pensamiento en el caso de Mauritania (art. 10) y la libertad de culto tal como es el caso en Marruecos (art. 41) y de Afganistán (art. 2). Por último, la falta de reconocimiento de ninguna de sus facetas se observa en las Constituciones de Qatar, Yemen, Maldivas y Comoras.

Partiendo de que "no hay vida humana que no esté constituida por ciertas creencias básicas y, por decirlo así, montada sobre ellas"35, la libertad religiosa debe engolar, y de hecho engloba, la libertad para creer o no creer, para tener unas u otras convicciones religiosas; la libertad para expresar y manifestar esas convicciones religiosas y hacer partícipes de ellas a otros, y la libertad de adecuar el comportamiento individual a los dictados de estas convicciones y de no ser compelido a comportarse en contra de las mismas $^{36}$. Su núcleo esencial es interno, pues pertenece a la esfera íntima del individuo, y viene constituido por la libertad que ha de tener toda persona para formar libremente en su interior sus propias conviccio-

\section{4. ÍDEM.}

35. Ortega y Gasset, J., Ideas y creencias, Espasa Calpe Argentina, Buenos Aires-México 1940, p. 12.

36. Barrero Ortega, A. La libertad religiosa en España, Centro de Estudios Políticos y Constitucionales, Madrid, 2006, p. 95. 
nes personales en materia de religión. Si el mayor indicador de la dignidad del hombre es su capacidad racional y su condición moral para determinar lo que debe hacer o no hacer ${ }^{37}$, el compromiso de los poderes públicos habrá de consistir en posibilitar, o cuanto menos no impedir, el desarrollo de esta faceta de su dignidad.

El correlato primordial de la igualdad es la no discriminación por razón de religión. De ahí la proscripción de cualquier trato privilegiado, distinción o exclusión que, con base en motivos religiosos, tenga por resultado la supresión o el menoscabo de la igualdad en la titularidad y en el ejercicio de la libertad religiosa.

En línea con lo anterior, una precisión se hace evidente. En Islam se reconoce la soberanía de Dios en el sentido de encarnación de un poder total. Entendida, esta soberanía, sin matizaciones conllevaría la negación de la autonomía individual y del libre albedrío, y de ahí la exención de toda responsabilidad del ser humano desprovisto del poder de decisión sobre sus actos. Sería absurdo suscribir esta intelección, pues la aludida soberanía despliega su potencial únicamente sobre el mundo físico animado por leyes, pero, como corolario de la responsabilidad y la rendición de cuentas que se prevé en el más allá, de ningún modo puede sostenerse lo mismo respecto del ser humano que se le reconoce un estatus de libertad. Añádase a ello, como consecuencia lógica de esta soberanía divina, que el ser humano resulta colocado en una posición de igualdad radical, y de ahí que goce de una libertad total respecto de las decisiones que tome o quiera tomar en su vida sin que nadie se pueda arrogar el poder de inhibirla o de proscribirla. De lo que

37. Barrero Ortega, A. La libertad religiosa en España..., Op. cit, p. 97. resulta que esta libertad abarca también el ámbito de la fe y de las creencias.

Obsérvese como del mismo Corán ${ }^{38}$ puede inferirse semejante noción de la libertad religiosa tal como se ha venido definiendo. Así por ejemplo, cuando afirma que "vosotros tenéis vuestra religión, yo tengo la mía" o cuando dispone que "no hay coacción en la religión" ¿no queda claro que esta expresión lleva implícita una noción de libertad religiosa? Estas citas concuerdan plenamente en su contenido con la denuncia de Voltaire expresada como sigue: "El principio universal de uno y otro es, en todo el globo: "No hagas lo que no quisieras que te hagan". No se comprende, por tanto, según tal principio, que un individuo pueda decir a otro: "Cree lo que yo creo y lo que no puedes creer, o morirás" (...) "Cree o te odio; cree o te haré todo el perjuicio que pueda; salvaje, no tienes mi religión, por tanto no tienes religión: debes provocar horrores a tus vecinos, a tu ciudad, a tu provincia"39. Coincidencia entre Religión y filosofía que, de acuerdo con Habermas, a través de un intercambio recíproco hace que la Filosofía aprenda de los contenidos de la Teología y que ésta se vea enriquecida por los planteamientos de aquélla ${ }^{40}$.

Destacada la concordancia, cuanto menos en este aspecto, entre filosofía y Religión ${ }^{41}$ afirmamos que es cierto que, en

38. La edición consultada a efectos del presente trabajo es Traducción-comentario del Noble Corán, Darussalam editores y distribuidores, Riyadh-Houston-Lahore, 1997.

39. Voltaire. Tratado sobre la tolerancia, Fontana. Ediciones Brontes S.L., 2011, p. 42.

40. Habermas. J., Entre naturalismo y religión. Barcelona, Paidós, 2006, p. 14.

41. "La filosofía, la sola filosofía, esa hermana de la religión, ha desarmado más que la superstición había ensangrentado tanto tiempo; y la 
palabras de Meyes-Bisch"42, "el Estado "culturalmente desnudo" que se pretende al margen de las culturas, es un monstruo respecto a las libertades reales: aquellas que necesitan ser protegidas y sostenidas las vías de transmisión de la riqueza cultural. (...) En el seno de lo cultural, lo religioso está en primera línea, pues propone una visión integrada de la ética y de la política, con la condición de que la (religión) misma sea un testimonio y un factor de hospitalidad cultural". También añadimos que no es menos cierto que en el origen de la mayoría de los conflictos laten casi siempre factores culturales, y en palabras de Amin Maalouf de "identidades asesinas" que traen causa de la configuración de una colectividad dominante, endogámica y excluyente, sino anuladora, de los diferentes. Colectividades cerradas que niegan a los individuos que la integran toda posibilidad de construir su propia identidad de manera diferente, abierta y plural, e incluso para abandonar la identidad cultural y/o religiosa originaria ${ }^{4}$. El remedio, en Palabras de Voltaire, sería "someter esta enfermedad del espíritu al imperio de la razón, que lenta, pero infaliblemente, ilumina a los

mente humana, al despertar de su enajenación, se ha sorprendido de los excesos a los que la había arrastrado el fanatismo". Voltaire. "Tratado sobre la tolerancia”, op.cit., p. 34.

42. Meyer-Bisch, P. "Les droits culturels, axes d'interprétation des interactions entre liberté religieuse et neutralité de l'Etat", en Tagliarini. F. (ed.), Diritti dell'uomo e libertà religiosa, Jovene Editore, Napoli 2008, pp. 31-32. Citado por Vega Gutiérrez, A. M., "El derecho a cambiar de Religión. Op.cit., p.165, nota en pie de página 12. Traducción de Vega Gutiérrez, A. M.

43. Vega Gutiérrez, A. M., "El derecho a cambiar de Religión. consecuencias jurídicas de la pertenencia y disidencia religiosa en el derecho comparado". op. cit, pp. 167-168. hombres. Esta razón es dulce, es humana, inspira indulgencia, ahoga la discordia, fortalece la virtud, hace amable la obediencia o las leyes, en mayor grado de lo que la fuerza las impone"44. Dicha razón nos enseñaría que el pensamiento fuerte, sea de origen divino o humano, no necesita de la violencia para verse reconocidos tanto su valor como su utilidad de donde deriva su fuerza. Un pensamiento débil, al contrario, estará siempre al socaire del impulso humano guiado por intereses soterrados para imponer su propia razón por la fuerza. Arrogarse el derecho de defender cualquier religión o cualquier ismo laminando aquel que no comulga con sus postulados es, por mor de la arrogancia del ignorante, el derecho de la intolerancia que "es, por tanto, necio y salvaje: es el derecho de los tigres, pero mucho más terrible, porque los tigres sólo matan para comer, mientras que nosotros nos hemos aniquilado por los párrafos de unos textos"45.

De ahí que quepa afirmar que el ambicioso proyecto de la integración de la diferencia en los Estados arabo-musulmanes exige un tratamiento de la libertad religiosa que estuviese a la altura de las circunstancias. Ciertamente, puede decirse que no desmerece del mismo el que le concede la Constitución libanesa a este asunto en su artículo 9 al disponer que "La libertad de conciencia es absoluta. El Estado al cumplir con las obligaciones de adoración a Dios, respeta todas las religiones y ritos y garantiza el libre ejercicio de los cultos religiosos bajo su protección, siempre que ello no perturbe el orden público. El Estado garantiza, asimismo, a los ciudadanos de cualquier culto el respeto

44. Voltaire. Tratado sobre la tolerancia, op.cit., p. 40.

45. ÍDEM., pp. 42-43. 
del régimen de los estados personales y los intereses religiosos"46.

No se menosprecie, pues, lo provechoso que puede ser para un Estado renunciar a toda clase de confesionalidad o de laicidad excluyente como medio de atajar los intentos protagonizables por cualquier comunidad religiosa nacional de imponerle su libro sagrado a los demás.

\section{El derecho de abandonar su religión y de su manifestación pública}

Tal como ha quedado apuntado, el núcleo de la libertad religiosa no se limita al fuero interno de la persona. Integra también la libertad de manifestar al exterior esas convicciones, formadas interiormente, y de comportarse conforme a la religión profesada. Se trata de garantizar la posición jurídica en la que queda situado el individuo en su relación con los poderes públicos y con los particulares respecto de esas manifestaciones de su personalidad. De ahí la imposibilidad para el ordenamiento estatal de cualquier valoración positiva o negativa de la diferentes expresiones religiosas de la comunidad ${ }^{47}$.

Como manifestación del alcance limitado de la libertad religiosa en los Códigos penales de cuatro Estados arabo-musulmanes, la apostasía viene tipificada como delito

46. Una versión española de la Constitución libanesa vigente puede consultarse en https://wipolex.wipo.int/es/text/184204.

47. Roca Fernández, M.J., "La neutralidad del Estado: fundamento doctrinal y actual delimitación en la jurisprudencia", Revista Española de Derecho Constitucional, vol. 48, 1996, pp. 251-272. castigado con la pena capital ${ }^{48}$. Se trata de Yemen (art. 259), Mauritania (art. 306), Qatar y de Sudán (art. 126). En los demás países nada se dice respecto del apóstata, por lo que no ha lugar a sanciones ni a efectos jurídicos de ninguna índole.

Dícese, como fundamento de legitimidad de esta pena, que su origen es religiosotextual. Lo que viene a significar que puede ser de extracción coránica o venir recogido en algún relato del profeto Mohamed.

Si el Corán prevé explícitamente el caso del musulmán que decide dejar el Islam, no establece ninguna pena para el apóstata y menos la pena capital. El Corán que "es un libro sutil, que relaciona frases susceptibles de diferentes interpretaciones"49, se expresa al respecto en varios pasajes:

- "Quienes han vuelto sobre sus pasos después de que la Guía se les haya manifestado claramente, han sido abusados por el demonio que les ha dado un respiro" (s.47, 25).

- "¡Oh vosotros creyentes! Cualquiera de entre vosotros que rechace la religión..." (s.5, 54).

- "Aquellos de entre vosotros que se alejen de su religión y mueran incrédulos; vuestras acciones serán vanas en este

48. Vega Gutiérrez, A. M., "El derecho a cambiar de Religión. consecuencias jurídicas de la pertenencia y disidencia religiosa en el derecho comparado". Op. cit., p. 188.

49. Pisani, E. “Apostasía En el Islam ¿Hacia La libertad Religiosa?” Revista Criterio, 2016, p. 3. http://www.revistacriterio.com.ar/bloginst_new/2016/10/11/apostasia-en-elislam-hacia-lalibertadreligiosa/?utm source $=$ feedburner\&utm_medium $=$ email\&utm campaign $=$ Feed $\% 3 \mathrm{~A}+$ RevistaCriterio $+\% 28$ Revi sta + Criterio $\% 29$ 
mundo y en la vida futura, habitareis en el Fuego y seréis inmortales" (s.2, 217).

Con respecto a la pena prevista en el caso de la apostasía, los versos coránicos indican que será infligida en el más allá sin que quepa inferir otro castigo terrenal. Silencio coherente con otros pasajes que consagran la libertad religiosa tales como "no hay coacción en la religión" (s 2, 256) $\mathrm{y}$ "quien quiera creer, que crea, y quien lo quiera, que no crea" (s.18, 29).

En cuanto a la Sunna se cita el relato (hadit) en cuya virtud "Al que cambia de religión, matadlo" ${ }^{50}$, para justificar la eventual condena. Estas posiciones extremas encontraron eco en Marruecos, donde el Consejo Superior de los ulemas emitió una fatwa (dictamen) en abril de 2012, donde se establece la pena de muerte para el apóstata. Posteriormente, en el año 2016, en un documento titulado Sabil al-Ulemas (La vía de los sabios), el susodicho Consejo ha modificado su posición respecto del apóstata justificando este giro por una redefinición de la apostasía "no como una cuestión religiosa, sino un asunto político equiparable a la "alta traición"51. Este cambio de criterio parte de la distinción entre el apóstata que en conciencia decide cambiar de religión, de quien fomenta una guerra, o una sedición. He aquí otra interpretación acorde con el espíritu de la libertad religiosa leída en clave constitucional y/o a la luz de las referencias tradicionales.

50. Al no precisarse de qué religión se trata, una interpretación literal del citado dicho profético obligaría absurdamente a aplicar el castigo a cualquiera que abandone su religión.

51. https://www.la-croix.com/Religion/Islam/ Au-Maroc-apostats-sont-plus-passibles-peinemort-2017-02-08-1200823368. Fecha de la última consulta el 21/11/2018.
Los citados textos coránicos despojan, pues, de todo argumento religioso a los Estados que justifican la imposición de cualquier pena a aquel que pretende cambiar de religión. Aún más, hacen que parte de la doctrina como Aldeeb AbuSahlieh" ${ }^{52}$ que sostiene que "este derecho del musulmán de recurrir a los tribunales o de sustituir al Estado para castigar al apóstata se basa en el deber de prohibir lo censurable prescrito por el Corán: ¡Que constituyáis una comunidad que llame al bien, ordenando lo que está bien y prohibiendo $^{53}$ lo que está mal! Quienes obren así serán los que prosperen (3:4)", incurra en un grave error interpretativo.

Otra cuestión no menos polémica, por darse en muchos países arabo-musulmanes, y con estrecha relación con la libertad religiosa es la infracción del ramadán en público. Varios países árabes ${ }^{54}$ y de Asia castigan con la cárcel, y en algunos casos con latigazos, a quienes se atreven a infringir en público el ayuno en Ramadán e incorporan en sus legislaciones delitos específicos de ruptura pública del ayuno justificando la imposición de la pena por

52. Aldeeb Abusahlieh, S. A., "Le délit d'apostasie aujourd'hui et ses conséquences en droit arabe et musulman" Revue International de Droit Comparé. Vid. en el mismo sentido: Charfi, M., El Islam y la libertad de conciencia, en MARZAL, A. (ed.), Libertad religiosa y derechos humanos, Barcelona: 2004, 92 p, 142; Citado por Vega Gutiérrez. A.M., "Conversión y Derecho. La conversión religiosa en el Derecho internacional y en algunos ordenamientos jurídicos". SCRIPTA THEOLOGICA, Vol. 42, 2010, p. 757 , nota en pie de página 90 .

53. Subrayamos esta palabra para poner en evidencia el error de traducción del verbo "yanhawna" que significa prevenir y advertir.

54. En Marruecos el artículo 222 del Código Penal establece una pena de hasta seis meses de prisión para esta infracción. 
la necesidad de proteger los valores compartidos. ¿No concuerdan los leit motiv de esta prohibición con aquellos sostenidos por el legislador francés al proscribir el velo integral en los espacios públicos ${ }^{55}$ ? Sobre esta cuestión tuvo que pronunciarse el Tribunal Europeo de Derechos Humanos en su Sentencia de 1 de julio de $2014^{56}$, que descarta la contradicción de la ley francesa con las disposiciones del Convenio Europeo de los derechos humanos.

Coincidimos con Encarnación La Spina ${ }^{57}$ en el hecho de que apelar a la existencia de limitaciones significativas derivadas de

55. Loi $\mathrm{n}^{\circ}$ 2010-1192 du 11 octobre 2010 interdisant la dissimulation du visage dans l'espace public (JORF $\mathrm{n}^{\circ} 0237$ du 12 octobre 2010 page 18344 texte $n^{\circ} 1$ ). Art. 1 "Nadie puede, en el espacio público, llevar ropa destinada a ocultar su rostro" y art. 2 "A los efectos del art. 1, el espacio público se compone de las vías públicas y lugares destinados al servicio del gobierno público. II. La prohibición establecida en el art. 1 no se aplicará si se requiere o permite la ley o los reglamentos de la conducta, si se justifica por razones de salud o razones profesionales o si son parte de las actividades deportivas, celebraciones o eventos artísticos o tradicionales". El art. 3 "La ignorancia de la prohibición establecida en el art. 1, se castiga con una multa por los delitos de segunda clase [150 euros como máximo]. La obligación de cumplir el curso de ciudadanía mencionada en el art. 131-16 del Código Penal se podrá imponer al mismo tiempo o en lugar de la multa." También mencionar del Código Penal francés el art. 225-4-10 "El hecho de que alguien imponga una o más personas para ocultar sus rostros por amenazas, violencia, coacción, abuso de poder o abuso de poder, debido a su sexo, se castiga con un año de prisión y $30.000 €$ de multa. Cuando el hecho se cometa contra un menor de edad, la pena se elevará a dos años de prisión y una multa de $60.000 €$ ".

56. STEDH de 1 de julio de 2014, (GC) SAS v France Application n ${ }^{\circ}$ 43835/11.

57. La Spina, E. "El «valor de la convivencia» como argumento fuerte y débil para la prohibi- la protección superior de un cuerpo mínimo de valores compartidos anula las cláusulas establecientes del pluralismo y de la diversidad, pues como mucho puede dar lugar a un limitado margen de tolerancia, extremadamente resbaladizo hacia ciertas prácticas estigmatizadas, que no permite construir la convivencia social desde esos valores compartidos. De igual modo, añade la citada autora que, invocar el denominado "patriotismo constitucional"58 cercena también las posibilidades de construir una sociedad intercultural o con espacios de interacción y de diálogo con los otros ${ }^{59}$.

En general, los argumentos que niegan la pluralidad abarcan desde demandas de sumisión o de asimilación buscando la represión de la diferencia o la incorporación de los desiguales al grupo culturalmente dominante, hasta argumentos burdos basados en el respeto del orden público o la legitimidad derivada de la necesidad de asegurar la cohesión social. Con base en estos argumentos se introducen formas de intervención, represivas o asimilacionistas informadas por los principios y la cultura del grupo dominante, tendentes a anular, o cuanto menos silenciar las diferencias culturales y a erradicar las prácticas de los grupos minoritarios o no hegemónicos ${ }^{60}$. He aquí buenos argumentos para adoptar lo que Arkoun denomina

ción del velo integral en la jurisprudencia europea". AFD, 2016 (XXXII), p. 400.

58. Habermas, J., Patriotismo constitucional, La inclusión del otro, Barcelona, Paidós, 1999, p. 120.

59. La Spina, E. "El «valor de la convivencia» como argumento fuerte y débil para la prohibición del velo integral en la jurisprudencia europea”. Op.cit., p. 400.

60. La Spina, E. "El «valor de la convivencia» como argumento fuerte y débil para la prohibi- 
como crítica de la razón islámica clásica o dogmática ${ }^{61}$.

En esta lógica, la penalización de la ruptura pública del ayuno podría dar lugar a un pluralismo selectivo, o cuanto menos de reducida manifestación, lo que merma la libertad de expresión de opciones religiosas o no religiosas, y de una tolerancia limitada que sólo atiende a la moral dominante. Una cita de Lutero resulta oportuna como colofón a este apartado.: “... nadie puede creer o no creer por mí (...). Creer o no creer, por tanto, depende de la conciencia de cada cual (...); también éste [el poder secular] ha de estar contento, ha de ocuparse de sus asuntos y permitir que se crea de ésta o de aquella manera, como cada uno quiera y pueda, sin obligar a nadie. El acto de fe es libre y nadie puede ser obligado a creer. Se trata, en realidad, de una obra divina que viene del Espíritu y que, por consiguiente, ningún poder la podría hacer o imponer"62.

\section{Posibles vías interpretativas de esta miscelánea}

Desbordaría con mucho el objetivo al que atienden estudiar con el detenimiento debido cómo se las arreglan en estos Estados para solucionar las inevitables fricciones que, de seguro, se producen en sus ordenamientos entre ambas coordenadas. Sea como fuere, por si fueran pocas

ción del velo integral en la jurisprudencia europea”. Op.cit., p. 400.

61. Léase al respecto Cepedello Boiso, J. "Mohammed Arkoun Y La Crítica De La Razón Jurídica Islámica", Cuadernos electrónicos de Filosofia del Derecho, vol. 24, 2011, pp. 65-95.

62. Lutero, M. "Sobre la autoridad secular: hasta dónde se le debe obediencia (1523)". En Escritos políticos, Madrid, Tecnos, 1986, pp: 46 y 47. las contradicciones que, en los tiempos presentes, desgarran al mundo árabemusulmán ${ }^{63}$, ha de sumarse esta última a la lista que, encabezada por el debate entre «la adhesión a su herencia intelectual y cultural y la modernidad», ofrece al respecto el profesor Yadh Ben Achour. Quien, a la vista de tales contradicciones no duda en hablar de la esquizofrenia histórica en la que viven los países árabes ${ }^{64}$.

Sin ánimo de ser exhaustivos, a efectos del presente trabajo pasamos a exponer algunas posibles vías de interpretación de las mencionadas coordenadas de diferentes fuentes de inspiración cuando las mencionadas fricciones tienen proyección pública y toca afrontarlas.

\subsection{Interpretación sistemática}

Interesa subrayar que cuanto se lleva dicho permite volver a poner de manifiesto cómo a pesar de que las técnicas constitucionales clásicas son utilizadas por estas Constituciones, los sistemas políticos consagrados en su virtud no pueden confundirse con los regímenes que inspiraron el uso de dichas técnicas, cuyo marco conceptual se configuró dentro de las coordenadas individualistas impregnadas del naturalismo, el liberalismo y el relativismo propios de la ilustración. Interesa subrayarlo porque, en los países arabomusulmanes, una lectura descontextualizada de la terminología acuñada en occidente y consignada en el texto constitucional podría mover a confusión. Dicho

63. Terol Becerra, M.J, Prólogo al libro Poder constituyente en el mundo árabe, Junta de Andalucía, Sevilla, 2012.

64. Cfr. Ben Achour, Y., «Les constitutions des pays arabes. Conclusions generales». En www. fdsp.usj.edu.lb/cedroma/. 
de otro modo, la clonación terminológica no siempre ha conllevado una clonación conceptual.

En este sentido resultan esclarecedoras las palabras del profesor Terol Becerra ${ }^{65}$ al afirmar que si el rasgo quizá más destacado de la globalización, en ausencia del cual no se llega a aprehender la noción de tal, es su acaecer autónomo o independiente de la voluntad estatal, e incluso a despecho de la misma, la Constitución escapa a la posibilidad de convertirse en su objeto, por tratarse de un fenómeno nacional. De modo que de ningún régimen constitucional puede esperarse que alcance dimensiones supranacionales de no mediar la colaboración al respecto de los Estados concernidos. Es más, aun cuando cualquier Constitución admita contemplársela desde la perspectiva propia de la cultura y ser considerada una de sus especies, ninguna participa de la nota característica que muestran los bienes de esa naturaleza, en virtud de la cual circulan libremente más allá de las fronteras nacionales en donde nacieron y pueden llegar a convertirse en patrimonio de la humanidad.

Aun dando por buena la mencionada afirmación del profesor Ben Achour, no le cabe al jurista, al abordar cualquier texto de esta naturaleza compuesta, sino partir en su labor interpretativa, de la evidencia de que las partes de cualquier orden constitucional no han de ser considerados como elementos separables cuya suma produzca la Constitución, sino de momentos que se integran en una unidad, que adquieren significado en el seno de

65. Terol Becerra, M.J, "Globalización Versus Universalización constitucional en el Mediterráneo. Propuesta metodológica para un análisis de la diversidad", Revista de Derecho Político, vol 60, 2004, p. 79. ella y que se condicionan mutuamente, de modo que la modificación en la estructura parcial de cada uno de ellos produce sistemáticamente una transformación en la de las demás partes integrantes y, por consiguiente, en la estructura total. En absoluto puede tomárselas como un conjunto de compartimientos estancos y aislados, sino como una totalidad ordenada, una estructura general, en la que las partes integrantes, es decir, las estructuras particulares, se conexionan en el todo y están unidas por un condicionamiento recíproco.

Ésta sería una manera, y a nuestro juicio de las más correctas en términos jurídicos, de abordar e interpretar estos textos constitucionales. Ello deriva, como ha quedado expuesto, del carácter sistemático de los mismos y la interacción mutua que se da entre sus disposiciones cualquiera que sea su origen. El sentido de cualquiera de las disposiciones contenidas en dichos textos no puede llevar a negar el sentido de las demás. La conciliación entre las diferentes disposiciones, sin imponer una prevalencia de unas sobre otras, ha de guiar toda labor de interpretación. Hacer lo contrario supondría silenciar una parte en beneficio de la otra, lo que haría del interprete un legislador constituyente.

\subsection{La Constitución nominal no susceptible de interpretación alguna}

La segunda opción, que parte de la confusión entre poder constituyente y poderes constituidos, consistiría en renunciar a reconocerle poco valor jurídico a las disposiciones de estas Constituciones, siendo de este modo su inclusión en las mismas un mero saludo honorífico a las deman- 
das sociales sin que ello vaya acompañado del compromiso de atenderlas en su totalidad. De ahí que esta segunda opción convierta los textos constituciones en puro nominalismo ${ }^{66}$ huero de todo contenido, y que no rijan la dinámica del proceso político puesto que no se adapta a sus normas. Como corolario de ello, la Constitución carece de realidad existencial y que la fórmula política haya de buscarla, prestando la expresión usada por Lassalle, en los verdaderos factores de poder.

A mayor abundamiento, estas Constituciones pueden sufrir la amenaza de poder llegar a ser puramente semánticas y de resultar desprovistas de todo contenido normativo, por lo que cualquier coincidencia de sus disposiciones con la realidad sería algo menos que fruto del azar.

En este marco, la labor interpretativa llevada a cabo en clave política en sede parlamentaria y en clave jurídica por los órganos de control de constitucionalidad de la ley, ahí donde existen, participa de un proceso de vaciamiento de la sustancia de la Constitución, o de des-constitucionalización de la misma, haciendo que su utilidad se acantone en lo meramente decorativo.

\subsection{La interpretación basada en el valor desigual de las disposiciones constitucionales}

La tercera alternativa, no menos problemática en términos jurídicos, consistiría en establecer una jerarquía intra-constitucional que supondría la intelección de ciertas disposiciones a la luz de aquellas que le sean, sin criterio jurídico alguno, supra-ordenadas. No hay que desatender

66. Löwenstein. K, Teoría de la Constitución, Ariel, Barcelona, 1976, pp. 216 y ss. el posible recurso a esta alternativa, pues supondría la suspensión parcial del pacto constituyente y por tanto de la paz social y política que del mismo derivan. Atribuirle arbitrariamente una prevalencia a unas coordenadas sobre otras reduciría el pluralismo que dichas Constituciones recogen en su seno a una mera proclama. Sobre este particular interesa llamar la atención sobre el riesgo que arrostra cualquier Estado de comprometer seriamente su futuro si ignora las peculiaridades privativas de las comunidades humanas ubicadas en su territorio, o pasa por alto sus posibles pretensiones de imponerse sobre las restantes.

En línea con esta vía interpretativa, parte de la doctrina sostiene que, cualquiera que sea la acogida del derecho a la libertad religiosa, en su plenitud o de modo parcial, estas cláusulas han de ser interpretadas dentro de los límites de la Ley islámica ${ }^{67}$. Esta afirmación supone la primacía de la Ley islámica sobre las demás disposiciones constitucionales, aserción que no concuerda, a nuestro parecer, con el principio de unidad del ordenamiento jurídico. A mayor abundamiento, se da por supuesto la existencia de una "Ley" islámica. La noción de Ley expresa la normalidad de los comportamientos individuales y anuda al comportamiento "anormal" sanciones jurídicas impuestas por el poder público. Resulta muy discutible que todas las prescripciones de índole religiosa respondan a esta definición, pues varios puntos de divergencia se dan entre las diferentes escuelas de interpretación a fuer de la ausencia de disposiciones textuales que obedezcan a su estructura normativa. La ley, si aceptamos que existe, sería la traducción interpretativa de los textos de referencia por parte de las mencionadas escuelas, y su adopción como fuente de Derecho por

67. ÍDEM. 
parte de algunos Estados. Y aún en este último caso, su superioridad respecto del resto de disposiciones constitucionales es más que discutible.

En definitiva, nuestra posición a favor de una interpretación sistemática de todas las disposiciones constitucionales y de reconocimiento del influjo mutuo entre ellas nos lleva, además de establecer cauces de conciliación de la parte de cuño moderno con el bloque tradicional-islámico, a llevar a cabo una hermenéutica abierta de éste último en aras de liberarlo de la manipulación del poder político, social o religioso y de entregar este poder a la comunidad de creyentes para que sean ellos mismos los que formulen el sentido de su vida ${ }^{68}$. A este respecto apunta el profesor Cepedello Boiso que "la diversidad empírica del sentido religioso es parte de la diversidad de opiniones humanas acerca del sentido de la vida en general, lo que supone un valor positivo en el contexto de la vida moderna"69.

\subsection{La interpretación basada en el pluralismo jurídico}

En línea con las coordenadas de diferente signo, animadas por el derecho a la diferencia, que las Constituciones arabomusulmanes albergan en su seno, acaso no resulta descabellado reconocer la existencia de un pluralismo jurídico débil en palabras de Griffiths $^{70}$ en cuya virtud se mantiene el centralismo pero reconociendo distintas estructuras jurídicas dentro del mismo Derecho estatal.

68. Cepedello Boiso, J. "Modelos de Organización política de la Umma en la historia del pensamiento islámico.” Op.cit... p. 33

69. ÍDEM.

70. Griffiths, J., "What is legal pluralism?", Journal of Legal Pluralism, vol. 24, 1986, pp. 8 y ss.
En esta misma línea podría adoptarse la reflexión del profesor Ramón Soriano que distingue un pluralismo "externo" e "interno" o "pluralismo de "derechos" y un "pluralismo jurídico estatal" respectivamente, identificando el primero con el "pluralismo de derechos" que consistiría en la coexistencia de una pluralidad de derechos en el mismo territorio o espacio geopolítico, y al segundo con el "pluralismo jurídico estatal" para referirse al pluralismo de fuentes jurídicas dentro de un mismo derecho, como es el derecho estatal ${ }^{71}$.

Semejante planteamiento parece haberse practicado en la historia islámica al rechazarse de plano la aplicación de la ley islámica a los no musulmanes, derivando la resolución de los casos planteados a sus normas de referencia. Sirva como ejemplo de ello no sólo la no alteración de matrimonios incestuosos o de la poliandria, sino el hecho de que la doctrina se haya ocupado de encontrar soluciones legales acorde con las fuentes de inspiración o de las normas de referencia de cada colectividad.

Voltaire se hizo eco de este pluralismo en su Tratado sobre la Tolerancia en los siguientes términos: "El Gran Señor gobierna en paz veinte pueblos de diferentes religiones; doscientos mi griegos habitan tranquilos en Constantinopla; el propio Muftí nombra y presenta al emperador al patriarca griego. El sultán nombra obispos latinos para algunas islas de Grecia (...) Este imperio está lleno de jacobinos, nestorianos, monotelitas; hay coptos, cristianos de San Juan, judíos, guebros, banianos. Las crónicas turcas no mencionan ninguna sublevación suscitadas por alguna de esas religiones"72.

71. Soriano, R., Sociología del Derecho, Ariel, Barcelona, 1997, p. 361.

72. Voltaire. Op. cit. p. 35. 
Hoy por hoy, tratamiento parecido parece instaurase para afrontar el problema que supone la gestión de sociedades diversas y multiculturales. En 2007 Gran Bretaña reconoció oficialmente a los Tribunales Musulmanes de Arbitraje (Muslim Arbitration Courts), incluso con la aprobación del entonces Arzobispo de Canterbury, Rowan Williams. Se trata de tribunales informales, sin registros oficiales de actas y sin control sobre el nombramiento de los jueces: de la misma manera que la religión es informal -en el sentido de "no jerarquizada"73. Igualmente en Canadá existe, desde 2004, un "Instituto de Jurisdicción Civil" que juzga según la Sharía. Gracias a esto, cerca de un millón de musulmanes en Canadá podrían gozar de normas menos restrictivas ${ }^{74}$.

Igual proceder podría seguirse en los países de mayoría musulmana en beneficio del derecho a la diferencia. Si no es así en términos legislativos ${ }^{75}$ puede sostenerse una interpretación tendente a ello con base en el derecho a la diferencia.

\section{Conclusiones}

Estos antecedentes, junto con la evidente conexión entre fuentes textuales islámicas y libertad religiosa, cierran las puertas a interpretaciones dogmáticas y excluyentes que abundan en el pensamiento y en la práctica en varios países arabo-musulmanes, que son paradójicamente plurales

73. Losano, Mario G. "Revolución en el mediterráneo: ¿Hacia un islam democrático? El problema de la libertad de religión", Derechos Y Libertades, vol. 26, Época II, 2012, p. 26.

74. Losano, Mario G. "Revolución en el mediterráneo..." op.cit. 26-27

75. En Marruecos existen Códigos de familia para judíos y para cristianos. desde varias ópticas (racial, lingüística, religiosa, etc.).

El hecho de que la libertad religiosa resulte reconocida y garantizada por las fuentes textuales a los que remiten buena parte de las Constituciones arabo-musulmanes le dota forzosamente de lo que Häberle ${ }^{76}$ denomina como faceta institucional o jurídico-objetiva. De ahí que no sólo quepa exigirse la garantía de su protección por parte del poder público sino también de su promoción.

Sorprende, pues, que de facto, el pluralismo religioso sea común a la totalidad de los países arabo-musulmanes, pero de iure no se reconozca la libertad religiosa. A este respecto afirma con gran acierto Carré Olivier que el Islam tradicional viene configurado como una religión laica y que el problema para el mundo árabe no es inventar la laicidad que se da, sino pensar la realidad que niega ${ }^{77}$.

Como colofón de la presente reflexión no nos cabe sino suscribir plenamente las palabras de Vega Gutiérrez ${ }^{78}$ al afirmar que se trata de un desafío permanente de la humanidad. La integración plena de los «diferentes» sigue resultando muy problemática. La fórmula empleada por los nacionalismos laicistas (como la India de Nehru, la Turquía de Atatürk, la Rusia de Lenin, la China de Mao, o el Irán del Sha Reza Pahlevi) que consideraban a la religión como una muestra de ignorancia

76. Häberle, P., "Recientes desarrollos sobre derechos fundamentales en Alemania", Derechos y Libertades, 1993, p. 154.

77. Cfr. Carré, O, El Islam laico. ¿Un retorno a la Gran Tradición?, Bellaterra, Barcelona, 2000.

78. Vega Gutiérrez, A. M., "En derecho a cambiar de religión. Consecuencias jurídicas de la pertenencia y disidencia religiosa en el derecho comparado", op.cit, p. 164. 
y fanatismo no sólo no ha dado ningún resultado positivo sino que ha desencadenado graves conflictos y ha sido fuente de la violación sistemática de los derechos humanos, en especial, de la libertad religiosa. Y no le falta razón a la misma autora cuando añade que "de igual modo, el principio grociano "etsi Deus non daretur» sobre el que se han gestado la mayoría de los sistemas jurídicopolíticos europeos ha dado resultados ambivalentes. Pues, si bien, por una parte, propició la proclamación de las primeras declaraciones de derechos humanos, al enunciar las condiciones que conforme a la recta ratio posibilitan a los hombres libres e iguales convivir pacíficamente en una sociedad organizada mediante el derecho; por otra parte, acabó desterrando de la vida pública de las naciones las normas morales y la religión, en una versión del secularismo y de la laicidad más bien «necia» ${ }^{79}$, «integrista» ${ }^{80}$, e incluso «dogmática», como prefiere definirla el Relator Especial sobre formas contemporáneas

79. Con este adjetivo describe Haaland Matlary el concepto de laicidad defendido por una buena parte de Europa. En su opinión, «la lógica instrumental europea actual no puede servir como paradigma universal. (...) Este secularismo se plantea a su vez como el único válido con el que comparar otras culturas y civilizaciones, burlándose asi de su respeto por el pluralismo y el relativismo. Lo único que no está permitido criticar en el nombre del relativismo es la propia cultura europea. El paradigma europeo se concierte en el único políticamente correcto, y por eso comete la falacia lógica de afirmar que un grupo de valores es más válido que otros, sin admitir que debería entonces basarse en un conjunto de valores objetivos». Haaland Matlary, L, Derechos humanos depredados. Hacia una dictadura de relativismo, Cristiandad, Madrid 2008, pp. 230-231. El subrayado es de Vega Gutiérrez).

80. Rhonheimer, M, Cristianismo y laicidad. Historia y actualidad de una relación compleja, Rialp, Madrid, 2009, p. 132. de racismo, discriminación racial, xenofobia y formas conexas de intolerancia ${ }^{81}$. La creciente multiculturalidad de nuestras sociedades demanda nuevas fórmulas; se precisa repensar la laicidad y restablecer su prestigio."

No se desdeñe, pues, el beneficio que puede reportarle a un Estado plural, en tanto que compositum de comunidades humanas cultural y religiosamente diversas, reconocerles su respectiva idiosincrasia y hasta asignarles, por eso mismo, alguna dosis de autonomía, como medida facilitadora de la integración desde la colaboración y la participación. La paz social se ha convertido en una exigencia al Estado como también lo es la integración de todos los grupos humanos que en su seno cohabitan. Acaso no sean malos tiempos para garantizar el derecho a la diferencia también en los países arabo-musulmanes.

\section{Bibliografía}

Adnane, A., "Lectura en el principio de igualdad y filiación en el derecho de familia marroquí a la luz del socialismo jurídico de Antón Menguer", en Comentarios sobre el Derecho Civil y los pobres, Tirant Lo Blanch, Valencia, 2011.

Adnane, A., "Lecture croisée entre la Constitution marocaine et le cadre juridi-

81. Conforme a su diagnóstico, el fenómeno de la difamación de las religiones está ligado «al predominio cultural de un secularismo dogmático que alimenta las suspicacias ante lo religioso y se legitima en la defensa de la conquista histórica de la separación de la Iglesia y el Estado. (...) Esa intolerancia se expresa incluso en la negación del derecho democrático del ciudadano de referirse a sus creencias y valores espirituales y religiosos al pronunciarse en el ámbito político o ante grandes retos y crisis de la sociedad» (UN Doc. A/HRC/9/12, párr. 35). El subrayado es de la citada autora. 
que de la filiation. La nécessaire levée de la discrimination dérivant de l'article 148 du Code marocain de la Famille", Federalismi.it, Rivista de Diritto Pubblico Italiano, Comparato y Europeo, vol. 1, 2015.

Aldeeb Abusahlieh, S. A., "Le délit d'apostasie aujourd'hui et ses conséquences en droit arabe et musulman", Revue International de Droit Comparé.

Barrero Ortega, A. La libertad religiosa en España, Centro de Estudios Políticos y Constitucionales, Madrid, 2006.

Carré, O, El Islam laico. ¿Un retorno a la Gran Tradición?, Bellaterra, Barcelona, 2000.

Cepedello Boiso, J. "Mohammed Arkoun Y La Crítica De La Razón Jurídica Islámica", Cuadernos electrónicos de Filosofía del Derecho, vol. 24, 2011.

Cepedello Boiso, José., "Modelos de Organización política de la Umma en la historia del pensamiento islámico", CEFD, vol. 22, 2001.

Charfi, M., El Islam y la libertad de conciencia, en MARZAL, A. (ed.), Libertad religiosa y derechos humanos, Barcelona: 2004.

El Mandjra, M. Humillación. El Islam sometido por Occidente. Estudio preliminar de Ramón Soriano, Editorial Almuzara, 2005.

Fondevila. M., "Las Constituciones árabes desde el Derecho Constitucional Comparado", Revista General de Derecho Público Comparado, vol. 18, 2015.

Griffiths, J., "What is legal pluralism?", Journal of Legal Pluralism, vol. 24, 1986.

Haaland Matlary, L, Derechos humanos depredados. Hacia una dictadura de relativismo, Cristiandad, Madrid 2008.

Häberle, P., "Recientes desarrollos sobre derechos fundamentales en Alemania", Derechos y Libertades, 1993.
Habermas, J., Patriotismo constitucional, La inclusión del otro, Barcelona, Paidós, 1999.

Habermas. J., Entre naturalismo y religión. Barcelona, Paidós, 2006.

La Spina, E. "El «valor de la convivencia» como argumento fuerte y débil para la prohibición del velo integral en la jurisprudencia europea". AFD, 2016 (XXXII).

Losano, Mario G. "Revolución en el mediterráneo: ¿Hacia un islam democrático? El problema de la libertad de religión", Derechos y Libertades, vol. 26, Época II, 2012. Löwenstein. K, Teoría de la Constitución, Ariel, Barcelona, 1976, pp. 216 y ss.

Lutero, M. "Sobre la autoridad secular: hasta dónde se le debe obediencia (1523)". En Escritos políticos, Madrid, Tecnos, 1986.

Marsá Fuentes, Juan., La Globalización en el Mundo Árabe a través del Discurso de sus Intelectuales. Tesis doctoral, 2005. http://digibug.ugr.es/handle/10481/649. Fecha de la última consulta 23/11/2018.

Matthew E. Falagas, Effie A. Zarkadoulia, George Samonis. "Arab science in the golden age (750-1258 C.E.) and today", The FASEB Journal, vol. 20, 2006.

Meyer-Bisch, P. «Les droits culturels, axes d'interprétation des interactions entre liberté religieuse et neutralité de l'Etat», en TAGLIARINI. F. (ed.), Diritti dell'uomo e libertà religiosa, Jovene Editore, Napoli 2008.

Naciri, K. "Le Dualisme Constitutionnel au Maroc", "Les expériences constitutionnelles maghrébines», Journées d'études. Mustapha Chaker, 26 et 27 Abril 1987. Association Tunisienne de Droit Constitutionnel, Bibliothèque de Droit, de sciences politiques et économiques, Tome IX, 1987.

Ortega Y Gasset, J., Ideas y creencias, Espasa Calpe Argentina, Buenos AiresMéxico 1940. 
Palazzoli «Aussi s'agit-il d'un texte fondamentalement équivoque et qui donne un peu le vertige». In "Quelques réflexions sur la révision constitutionnelle du ler mars 1972» Palazzoli. C., R.J.P.E.M. vol. 1, 1976.

Pisani, E. "Apostasía En el Islam ¿Hacia La libertad Religiosa?" Revista Criterio, 2016.

Rhonheimer, M, Cristianismo y laicidad. Historia y actualidad de una relación compleja, Rialp, Madrid 2009.

Roca Fernández, M.J., "La neutralidad del Estado: fundamento doctrinal y actual delimitación en la jurisprudencia", Revista Española de Derecho Constitucional, vol. 48, 1996.

Soriano, R., Sociología del Derecho, Ariel, Barcelona, 1997.
Terol Becerra, M.J, "Globalización Versus Universalización constitucional en el Mediterráneo. Propuesta metodológica para un análisis de la diversidad", Revista de Derecho Político, vol 60, 2004.

Terol Becerra, M.J, Messaouidi, A, (coord.), El poder constituyente en el mudo árabe, Editorial Junta de Andalucía, Sevilla, 2012.

Vega Gutiérrez, A. M., "El derecho a cambiar de Religión. Consecuencias jurídicas de la pertenencia y disidencia religiosa en el derecho comparado". IUS CANONICUM, Vol. 51, 2011.

Vega Gutiérrez. A.M., "Conversión y Derecho. La conversión religiosa en el Derecho internacional y en algunos ordenamientos jurídicos". SCRIPTA THEOLOGICA, VOL. 42, 2010.

Voltaire. Tratado sobre la tolerancia, Fontana. Ediciones Brontes S.L., 2011. 